International Journal of Engineering \& Technology, $7(3.10)(2018) 160-163$
International Journal of Engineering \& Technology
SPC
Website: www.sciencepubco.com/index.php/IJET
Research paper

\title{
Analysis Cost Overruns, Delays and Risk Involved in Construction Management Using Primavera
}

\author{
T.Subramani ${ }^{1 *}$, P.Sivakumar ${ }^{2}$ \\ I* Managing Director, Priyanka Associates (Civil Engineers and Valuers), Salem, TamilNadu, India. \\ ${ }^{2}$ Correspondent, Kongu College of Arts and Science, Karur., TamilNadu, India. \\ "Corresponding author E-mail: tsmcivil2007@gmail.com
}

\begin{abstract}
Construction industry is taken into consideration as one of the maximum crucial industries in India. These phenomena may additionally have an effect on the development of construction industry in India. In addition to may additionally expose many establishments of construction to be destroyed. Delays in addition to disruptions are sources of capacity risks that studies are looking into techniques to manipulate along with technical, social, monetary, felony, economic, useful resource, creation and commercial. To evaluate the reasons of delays and conflicts are due to: layout modifications, delays in price to contractors, facts delays, investment troubles, bad challenge management, compensation problems and disagreement at the valuation of labor accomplished. On the other hand, time overrun, cost overrun, bad social effect, idling assets and disputes are the principle outcomes of delays and disruptions. The observe concludes the reasons of delays and disruptions and their outcomes placed construction projects at extremely great risk that have an impact on their performance the use of primavera.
\end{abstract}

Keywords: Analysis, Cost overruns, Delays, Risk and Primavera.

\section{Introduction}

In the construction industry, the goal of task manipulate is to make sure the initiatives end on time, inside finances and achieving other mission targets. It's a complex task undertaken via project managers in exercise, which entails constantly measuring development; comparing plans; and taking corrective actions whilst required. a spread of software program packages have come to be available to help the software of these undertaking manage methods, as an example Microsoft venture, Asta energy mission, Primavera, and so forth.

\subsection{Scope and Objectives}

Therefore objectives of this research are:

- To find out the reasons for cost and time overrun in construction projects;

- To prioritize the most important factors that affect construction time and cost, quality of works and health \& safety issues

\section{Methodology}

Fig. 1 shows the methodology of this study.

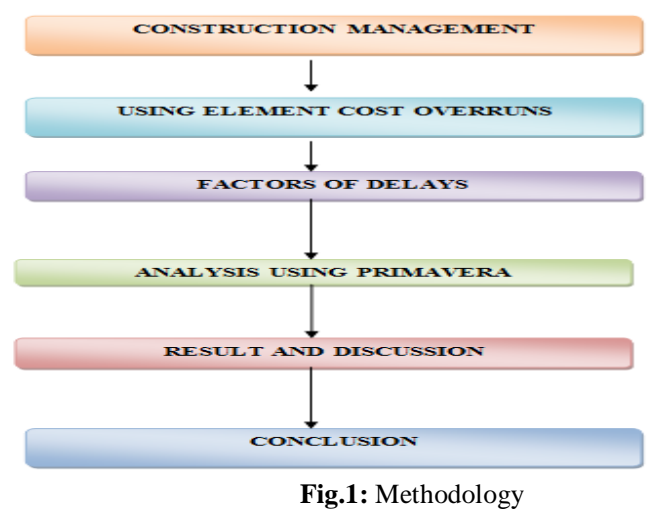

\section{Using Element Cost Overruns}

Fig. 2 shows the creation of WBS in P6

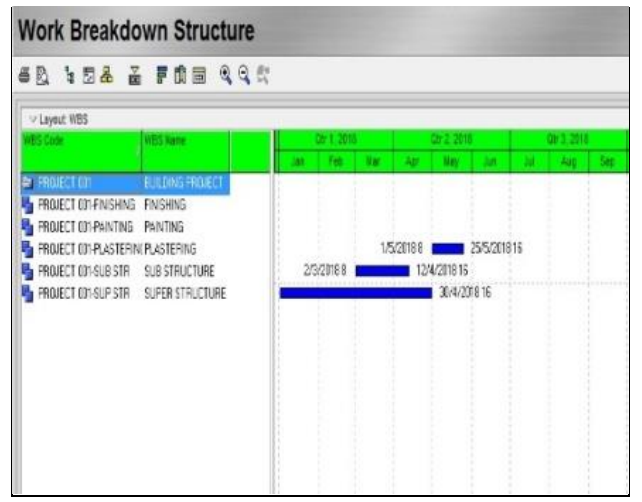

Fig.2: Creation of WBS in P6 


\subsection{Frequent Design Change during Construction Phase}

Changing design orders also affects the project schedule, alternate orders affects length and cost of construction project. Fig. 3 shows the cost overrun causes.

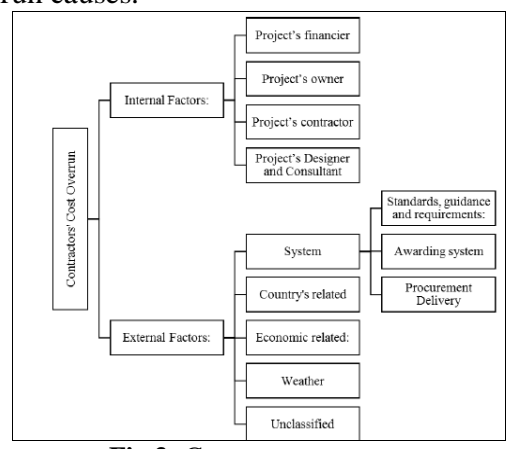

Fig.3: Cost overrun causes

\subsection{Frequent Design Change during Construction Phase}

Even though it is very not going that a undertaking may be added without any variant throughout the development stage, alongside procedure for processing design exchange orders negatively impacts at the cost of a construction project. Fig. 4 shows the activity details for substructure.

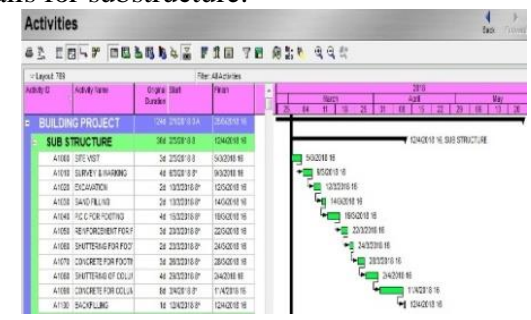

Fig.4: Activity details for substructure

Fig.5 shows the activity details for super structure.

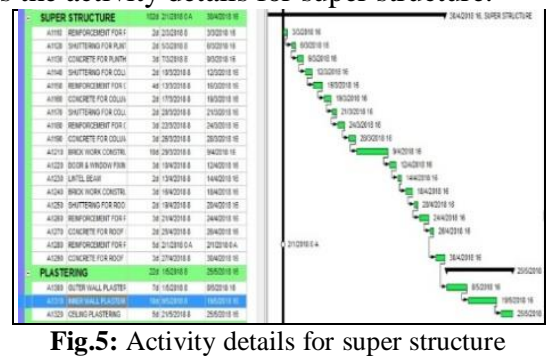

\subsection{Contractors' Financing}

Furthermore, negative controlling of price and cash glide all through the construction section would directly boom the price of implementing a undertaking, or it'd cause assignment put off that leads to financial penalties. In different words, if contractors meet economic difficulties, project development will be affected.

\subsection{Payment Delay}

Slow or delayed payment charge to contractors for finished works is a totally common complaint of contractors approximately undertaking's client.

\subsection{Lack of Contractors' Experience}

Construction projects are tending to end up extra complex and consequently region pressure on time (task duration) and expertise. A lack of contractor experience (and expertise) of the tasks' kind and vicinity might cause are work component for the challenge or delay which increases the value of implementing a project.

\subsection{Poor Cost Estimation}

Cost estimating may be defined because the system where an estimator arrives at an expenditure of assets important to finish a challenge according with plans and specifications. The training of a detailed price estimate for particular construction assignment calls for amassing, retrieving, and manipulating large quantities of independent, but associated, price and non- cost data and records in a time-effective manner.

\subsection{Poor Tendering Documents}

Immature tendering files had been diagnosed as causes of cost overrun in 13 out of seventeen researches. Several elements have prompted this issue which includes: the involvement of the designer as a consultant; conversation gaps occurring between among the contractor and dressmaker; inadequate information in the working drawings and a lack of coordination among the parties.

\section{Material Delay}

\subsection{Delays in Project}

In construction projects, in which the initiatives are to be done in line with the schedule to work the plan, delays are certain to manifest most of the time. Fig.6 shows the types of delays.

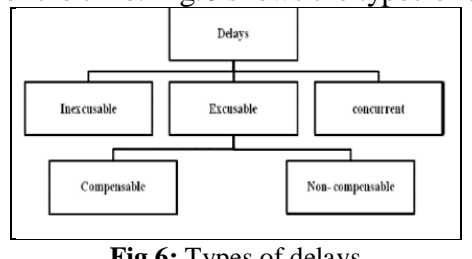

Fig.6: Types of delays

Delays may be labeled into two different categories with admire to liability: excusable and inexcusable. Fig.7 suggests the project delays.

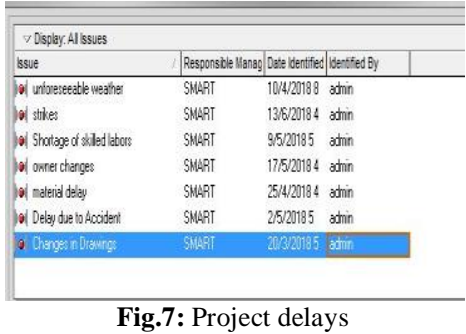

\subsection{Problem Associated with Material Management}

Most of the people of the material management issues on the jobsite include material monitoring, bid procurement, material buying, cloth procurement, storage troubles, material distribution, cloth harm and remanding.

\section{Risk Solving}

Fig. 8 shows the analysis of delay for substructure.

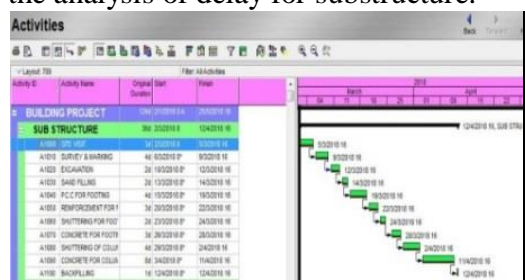

Fig.8: Analysis of delay for substructure 
Fig.9 shows the analysis of delay for superstructure.

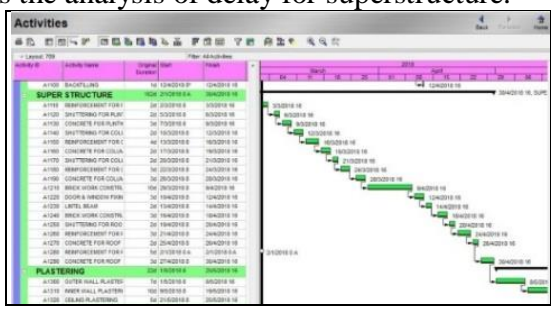

Fig.9: Analysis of delay for superstructure

\subsection{Importance of Time Value of Money}

There are three principal reasons why a dollar to get within the future has value much less than a dollar to get immediately. The first and most clear reason is the existence of fantastic fees of inflation which decrease the purchasing power of dollars at some point of the time.

\section{About Software}

\subsection{Primavera}

Primavera systems, Inc. become a non-public organization presenting challenge Portfolio management (PPM) software program to help undertaking-extensive businesses pick out, prioritize, and select mission investments and plan, control, and manipulate initiatives and task portfolios of all sizes. This model became said to decorate and amplify preceding work, improved reporting, and user enjoy and application integrations.

\section{Analysis Results}

Fig.10 shows the assigning calendar.

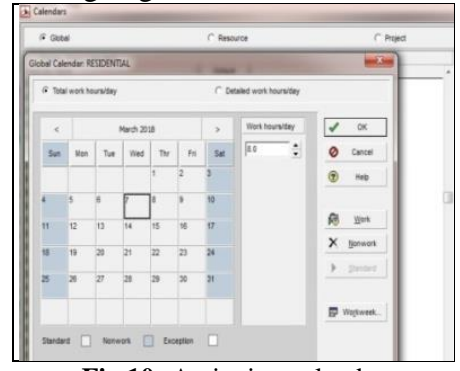

Fig.10: Assigning calenda

Fig. 11 shows the WBS Window.

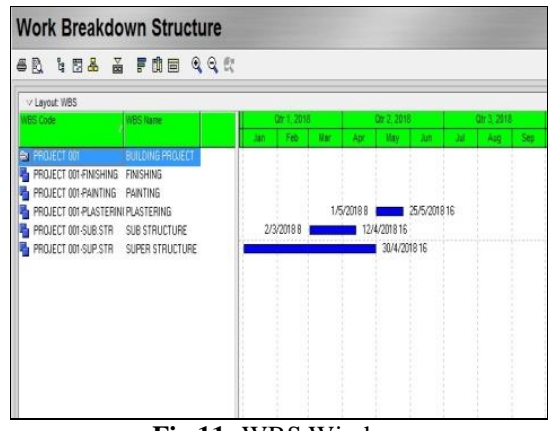

Fig.11: WBS Window

Fig. 12 shows the activities window 1.

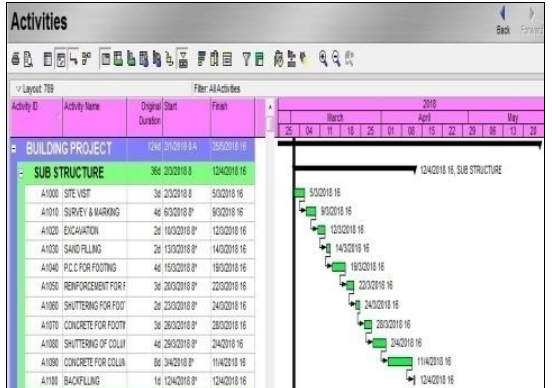

Fig.12: Activities window 1

Fig. 13 shows the activities window 2 .

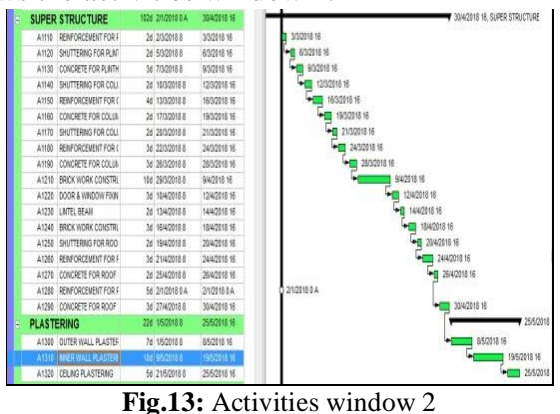

Fig.14 shows the activities completing window.

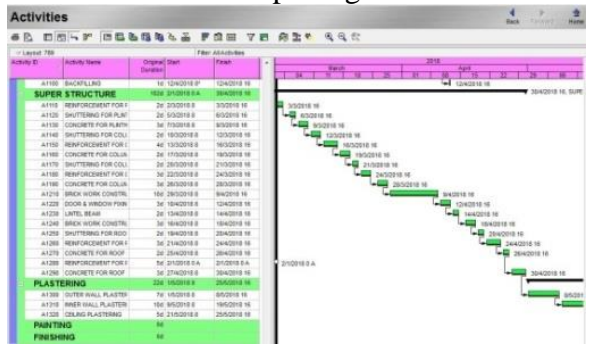

Fig.14: Activities completing window

Fig.15 shows the project issues for delay.

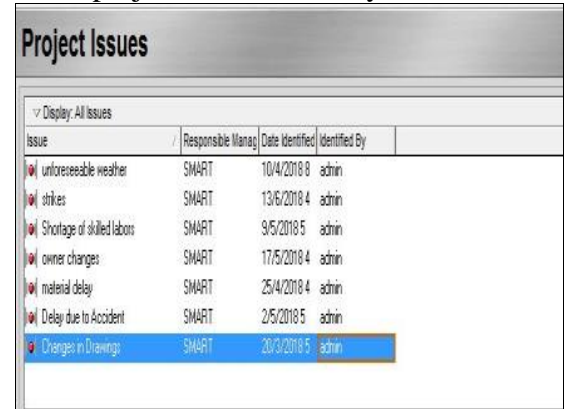

Fig.15: Project Issues for Delay

Fig.16 shows the project resources.

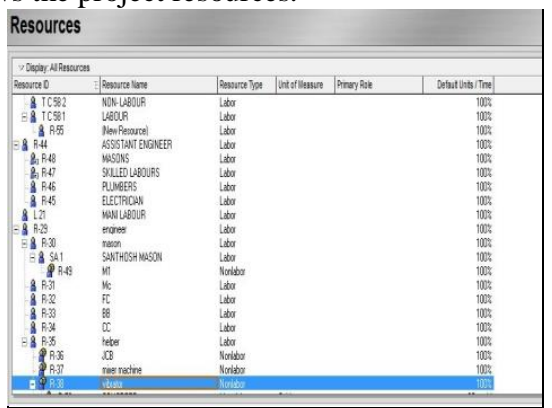

Fig.16: Project Resources

\section{Conclusion}

Time overruns and cost overruns are most commonly observed phenomenon in construction projects. The majority of 
construction projects are rated Inflation of materials; unfavourable climate conditions the involved parties because the most important factors while lack of overdue approvals, equipment and material whilst wished comes subsequent in row. After reading the facts it's far clear that the contribution of outside elements in put off of the construction assignment is extra than the consumer and consultant facet. The primary factors influencing them are terrible website online management and supervision, troubles with subcontractors, inadequate planning and scheduling of undertaking, trouble associated with material management and absence of coordination amongst stakeholders. Aside from this, its miles necessary to give adequate training to specialists and project engineers to decrease time overruns in regulating company policy.

\section{References}

[1]. T.Subramani., "Cost Estimation and Identification of Transport Infrastructure facility Projects in Salem", International Journal of Engineering and Technology, Vol.2, No.5, Pp 859 - 867,2012.

[2]. T.Subramani., P.Anitha., S.Sekar., "Health-Care Waste Management System", International Journal of Engineering Research and Applications, Vol. 4, Issue 6( Version 2), pp.255-258, 2014.

[3]. T.Subramani., N.Kanthasamy., "High End Solution For Advanced Civil Engineering Projects", International Journal of Modern Engineering Research, Volume. 4, Issue. 6 (Version 3), pp 49-53, 2014.

[4]. T.Subramani.,D.S.StephanJabasingh,J.Jayalakshmi. "Analysis Of Cost Controlling In Construction Industries By Earned Value Method Using Primavera", International Journal of Engineering Research and Applications, Volume. 4, Issue. 6 (Version 5), pp 145 $-153,2014$.

[5]. T.Subramani.T, P.T. Lishitha., M.Kavitha., "Time Overrun And Cost Effectiveness In The Construction Industry", International Journal of Engineering Research and Applications, Volume. 4, Issue. 6 (Version 5), pp 111- 116, 2014.

[6]. T.Subramani. , R.Lordsonmillar., "Safety Management Analysis In Construction Industry", International Journal of Engineering Research and Applications, Volume. 4, Issue. 6 (Version 5), pp 117- 120, 2014.

[7]. T.Subramani., A.Sarkunam.A, J.Jayalakshmi. "Planning And Scheduling Of High Rise Building Using Primavera", International Journal of Engineering Research and Applications, Volume. 4, Issue. 6 (Version 5), pp 134 - 144, 2014.

[8]. T.Subramani.,P.S.Sruthi., M.Kavitha. "Causes Of Cost Overrun In Construction", IOSR Journal of Engineering, Volume. 4, Issue. 6 (Version 3), pp 1 - 7, 2014

[9]. T.Subramani, M.Sekar , " Preplanning And Scheduling Of Road Construction By Using PPM", International Journal of Application or Innovation in Engineering \& Management (IJAIEM), Volume 4, Issue 5, pp. 234-244, 2015

[10]. T.Subramani, V.Jayaraman , " Analysis Of Construction Workers Migrate From Industries" , International Journal of Application or Innovation in Engineering \& Management (IJAIEM) , Volume 4, Issue 5, pp. 274-283, 2015

[11]. T.Subramani, S.Tamizhanban , " Supply Chain Management In Construction Site By Using SPSS Software" , International Journal of Emerging Trends \& Technology in Computer Science (IJETTCS), Volume 5, Issue 3, pp. 182-193 , 2016.

[12]. T.Subramani, S.R.Rajiv , " Improving Construction Efficiency And Productivity Of Industry Using SPSS" , International Journal of Application or Innovation in Engineering \& Management (IJAIEM) , Volume 5, Issue 5, pp. 239-250, 2016.

[13]. T.Subramani, K.Chinnadurai , " Construction Management And Scheduling Of Residential Building Using Primavera" International Journal of Application or Innovation in Engineering \& Management (IJAIEM), Volume 4, Issue 5, pp. 188-198, 2015

[14]. T.Subramani, Kurian Jacob , " Analysis Of Risk, Threshold And Issues And Monitoring Schedule Of Building Construction Using PPM Software" , International Journal of Emerging Trends \& Technology in Computer Science (IJETTCS), Volume 5, Issue 3, pp. 171-181, 2016.

[15]. T.Subramani, M. Muhammed Ansar, S.Priyanka , " Impact Of Prefabricated Technology And Equipment On The Profitability Using Primavera " , International Journal of Emerging Trends \& Technology in Computer Science (IJETTCS), Volume 6, Issue 3, May - June 2017, pp. 176-185 , ISSN 2278-6856.
[16]. T.Subramani, V.Annamalai ， S.Priyanka , " Management Information And Communication Technology In Construction Engineering Of Structures Using Primavera " , International Journal of Emerging Trends \& Technology in Computer Science (IJETTCS), Volume 6, Issue 3, May - June 2017 , pp. 186-197 , ISSN 2278-6856.

[17]. T.Subramani, V.Bhaskaran Nair, A.David, B.Mohamed Ghouse, N.Siva Kumar , " A Study Of Inventory Management System In Construction Industry " , International Journal of Application or Innovation in Engineering \& Management (IJAIEM), Volume 6, Issue 5, May 2017, pp. 304-311, ISSN 2319 - 4847. 